\title{
Effect of banana peel extract on storage stability of banana cv. Sagar
}

\author{
Rahman, M., Hossain, T.B., Hossain, M.S., Sattar, S. and *Das, P.C. \\ Department of Chemical and Food Process Engineering, Rajshahi University of Engineering and \\ Technology, Rajshahi-6204, Bangladesh
}

\begin{abstract}
Article history:
Received: 30 September 2019

Received in revised form: 30 October 2019

Accepted: 12 November 2019

Available Online: 15

November 2019
\end{abstract}

\section{Keywords:}

Banana,

Banana peel extract,

Shelf stability

DOI:

https://doi.org/10.26656/fr.2017.4(2).323

\section{Introduction}

Banana (Musa sp.) is one of the most common and popular fruits in Bangladesh. It is generally grown in all types of land available in Bangladesh which turns it as an important economic crop. Banana is also favorite to people because of its high calorific value and superior nutritional quality (Habiba, 2012). According to the book of BBS (2016), about 47,412.61 hector land were used for banana cultivation and the production was 7, 98, 012 metric tons in Bangladesh in the year of 2015-16. Because of its high production rate, banana ranks first of the total fruit production (Akter et al., 2013).

Aurore et al. (2009) mentioned the banana as a great source of vitamin A, vitamin B complex, vitamin C, manganese, potassium and fibers and also reported that a $100 \mathrm{~g}$ banana contains around $89 \mathrm{Kcal}$ energy, $74 \mathrm{~g}$ water, $1.1 \mathrm{~g}$ protein, $0.3 \mathrm{~g}$ lipid, $21.8 \mathrm{~g}$ carbohydrate, $2 \mathrm{~g}$ fiber, $1 \mathrm{mg}$ sodium, $385 \mathrm{mg}$ potassium, $8 \mathrm{mg}$ calcium, 30 mg magnesium, $0.4 \mathrm{mg}$ iron, $22 \mathrm{mg}$ phosphorus, $11.7 \mathrm{mg}$ ascorbic acid, $40 \mu \mathrm{g}$ thiamin, $70 \mu \mathrm{g}$ Riboflavin, $610 \mu \mathrm{g}$ Niacin, $80600 \mu \mathrm{g}$ Pantothenic acid, $470 \mu \mathrm{g}$ Pyridoxine and $23 \mu \mathrm{g}$ Folic acid. But in Bangladesh, every year huge amount of banana faces postharvest loss. According to Molla et al. (2012), the postharvest losses of bananas are around $26.63 \%$ in every year at different stages after harvesting till consumption which counts around 56.7 crore taka (Hassan, 2012). Higher temperature and humidity during harvesting season, inadequate storage facilities and quick spoilage characteristic are the main causes for this loss (Basel et al., 2002; Ullah, 2007; Islam, 2012).

Nowadays, a lot of techniques are practiced to preserve banana which includes modified atmosphere storage, controlled atmosphere storage (Stewart et al., 2005), edible film coating of polysaccharides (Kittur et al., 2001) etc. But applying these methods in developing countries like Bangladesh is limited because of limited technical facilities, high cost and unavailability of resources. So the development of easy and cost-effective method is truly essential for the reduction of a huge loss of banana. In the recent time, application of different plant extracts is getting significant interest to the researcher for extending the shelf life of different fruits and vegetables e.g. Nopal gel solution, neem leaf, guava leaf and lemon extracts for banana (Le and Truong, 2015; Siddiqua et al., 2018; Tabassum et al., 2018), neem leaf and banana pulp extracts for mango (Sarmin et al., 2018) etc.

Banana peel represents around $40 \%$ of the total weight of the fresh banana (Tchobanoglous et al., 1993) 
and has been discarded as waste (Shadma et al., 2014). It is a good source of bioactive compounds such as flavonoids, tannins, phlobatannins, alkaloids, glycosides, and terpenoids (Kapadia et al., 2015), which are reported to exert pharmacological effect, especially as an antioxidant, antidiabetic, anti-inflammatory, and antibiotic. Extracts of the banana peel possess potential antimicrobial activity against several microorganisms likely Staphylococcus aureus, Streptococcus pyogenes, Enterobacter aerogenes, Klebsiella pneumoniae, Escherichia coli, Moraxella catarrhalis and Candida albicans (Chabuck et al., 2013).

However, researches on the application of postharvest quality management of banana using BPE are limited till now. Considering the above points, this present study was undertaken to investigate the storage stability of banana based on observation of different parameters like weight loss, disease incidence, disease severity, color, flavor, texture, TSS and $\mathrm{pH}$ by spraying aqueous BPE on the outer surface of ripe banana.

\section{Materials and methods}

\subsection{Experimental design}

A total of five bunches of fresh ripe banana (free from any mechanical damage and disease) were collected from the field at Katakhali, Rajshahi, Bangladesh. Completely randomized design (CRD) was executed with three replications for each treatment taking twenty ripe banana fruits in each replication (Siddiqua et al., 2018). Samples were investigated for four treatments namely $\mathrm{T} 1=$ control (without treatment), $\mathrm{T} 2=\mathrm{BPE}$ of acetone, $\mathrm{T} 3=\mathrm{BPE}$ of $80 \%$ ethanol and $\mathrm{T} 4=$ $\mathrm{BPE}$ of distilled water.

\subsection{Preparation and application of banana peel extract}

A total of three types of banana peel extracts (BPE) were prepared by following and modifying the method described by Begam et al. (2018). About $15 \mathrm{~g}$ of banana peel was blended with $50 \mathrm{~mL}$ of distilled water and then the volume was made up to $100 \mathrm{~mL}$ in a 500 conical flask. Then, the flask was placed in a continuous shaker machine at a controlled temperature of $40{ }^{\circ} \mathrm{C}$ for $48 \mathrm{hr}$. After then, the aqueous extract was filtered through Whatman filter paper No. 4 and the filtrate was collected. Similar process was followed for the preparation of extracts using ethanol (80\%) and acetone. For $100 \mathrm{~mL}$ of each blended solution, on average around 53,43 and $56 \mathrm{ml}$ of distilled water, acetone and ethanol extract of banana peel was found respectively. From that, about $50 \mathrm{ml}$ of the BPE was sprayed afterwards on the surface of each replication of the samples and different parameters were observed up to complete spoilage of all bananas.

\subsection{Postharvest quality analysis}

\subsubsection{Observation of color, firmness and flavor}

The change in banana peel color was observed visually by keeping the banana under same intensity of light during study period and converting observed color into a numerical scale of 1-7 with slightly modification of the method of Dadzie and Orchard (1997), where score means yellowness of a sample and 1, 2, 3, 4, 5, 6 and 7 indicated $1=1-25 \%$ yellow, $2=26-50 \%$ yellow, 3 $=51-75 \%$ yellow, $4=76-100 \%$ yellow, $5=$ slightly brownish yellow, $6=$ highly brownish yellow, $7=$ rotten respectively. Firmness was determined on according to Dang et al. (2008) with 1-5 scale where $1=$ hard, $2=$ sprung, $3=$ slightly soft, $4=$ eating soft and $5=$ over soft. The flavor was also measured by sensory analysis of a scale $1-5$ as $1=$ excellent, $2=$ better, $3=$ good, $4=$ slightly bad and $5=$ worst, whereas $\leq 3$ was the acceptable limit here.

\subsubsection{Disease incidence and disease severity}

The percentage of disease-infected banana fruit was determined by counting the number of infected fruit. The visible black spots and visible symptoms were considered as a disease and calculated by following the equation suggested by Ullah (2007) as shown below:

$$
\text { Disease incidence }=\frac{\text { Number of infected banana }}{\text { Total number of banana }} \times 100 \%
$$

The percentage of the infected area on banana fruit indicates the disease severity which was determined visually by the numerical scale of 1 to 5 as $1=$ no disease, $2=$ small brown dots, $3=$ small brown areas, $4=$ turning brown, $5=$ black. The acceptable score was $\leq 3$.

\subsubsection{Total soluble solids (TSS)}

The total soluble solids was calculated by using digital refractometer (Model: DR 301-95, A. KRUSS Optronic Company, Germany), where a drop of banana juice was placed on to the prism of the device by squeezing the banana. Then, the device automatically showed the calculated percentage of brix on the instrument monitor in ${ }^{\circ}$ Brix.

\subsection{4 pH}

The $\mathrm{pH}$ of the banana was determined to observe the acidic or basic state of the banana samples. $\mathrm{pH}$ was determined by placing probes of $\mathrm{pH}$ meter (Model: PH500, CLEAN Instruments Co. Ltd., Shanghai, China) to the squeezed banana juice.

\subsubsection{Weight loss}

The physiological weight loss of the samples was calculated by following the formula by Kaur (2016) as 
follows:

Percentgae of weight loss $(\% \mathrm{WL})=\frac{\mathrm{IW}-\mathrm{FW}}{\mathrm{IW}} \times 100 \%$

Where $\% \mathrm{WL}=$ percentage of total weight loss; IW = initial weight of sample; and $\mathrm{FW}=$ final weight of sample.

\subsubsection{Shelf life}

The shelf life of the treated bananas was calculated by counting the number of days until the score of firmness retained less than or equal to 3 and color score remains less than or equal 5 . The average of the days required to reach the mentioned level was determined as the shelf life (Siddiqua et al., 2018).

\subsection{Data analysis}

All of the above determinations were carried out in triplicate whereas average and standard deviation was calculated and graphs were prepared by using Microsoft office excel 2013. Analyses of variances (ANOVA) were performed for shelf-life study to find out the significant differences between the pairs of means. For this, Fisher's least significant difference (LSD) procedure was performed at $\alpha=0.05$ using statistical software (StatGraphics, 1999).

\section{Results and discussion}

3.1 Effect of BPE on changes in color, flavor and firmness

As almost ripe bananas were taken for this study, the bananas showed significant changes in color, flavor and firmness during the observing days (Figure 1). The control (T1) showed the acceptable color limit (1 to 5) till day 3 , where the other treatments $\mathrm{T} 2$ showed almost 4.5 days, and $\mathrm{T} 3$ and $\mathrm{T} 4$ showed almost 5.5 days. This context indicates retention of color was better in case of the plant extract treated samples than the control samples which was in conformity with the results reported by Malik et al. (2015). There was drastic changes in the production of flavor for the control sample (T1) than other samples (T2, T3 and T4). The control (T1) crossed the acceptable flavor limit (3) on 3 days but the other treatments $\mathrm{T} 2, \mathrm{~T} 3$, and $\mathrm{T} 4$ retained for almost 4 days, 5 days and 4 days respectively. A similar observation was noted in the case of firmness of the samples as well. For firmness, the acceptable score was fixed as 3 (slightly soft) which was crossed on $3^{\text {rd }}$ day by the control sample (T1). On the other hand, the other treatments T2, T3, and T4 retained slightly soft firmness for almost 4 days, 5 days and 4 days respectively. Ullah (2007) found similar results and mentioned that the control banana fruit has a faster rate of firmness reduction than the treated samples. So from the above results, it is clearly revealed that the aqueous extract of banana peel had a great effect on retention of better color, flavor and firmness for longer storage of banana.

\subsection{Effect of BPE on disease incidence and disease severity}

Figure 2 represents the effect of the BPE on disease incidence and disease severity of the banana samples. The control samples (without treatment) showed the highest disease incidence rate than any other samples (T1, T2 and T3). The lowest disease incidence was recorded for the samples treated with ethanol extract (T3). $100 \%$ of the control samples were infected on the fifth day of storage period whereas $100 \%$ samples with
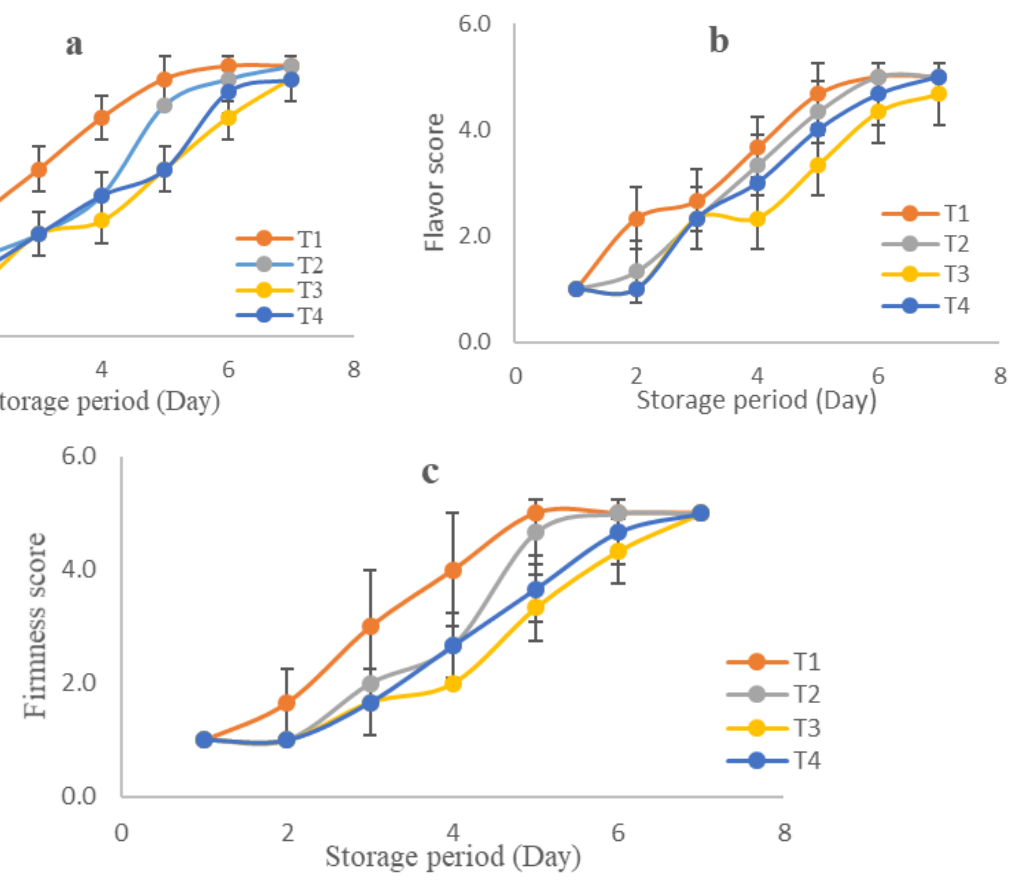

Figure 1. Effect of BPE on changes in scores of banana samples (a) color, (b) flavor and (c) firmness 

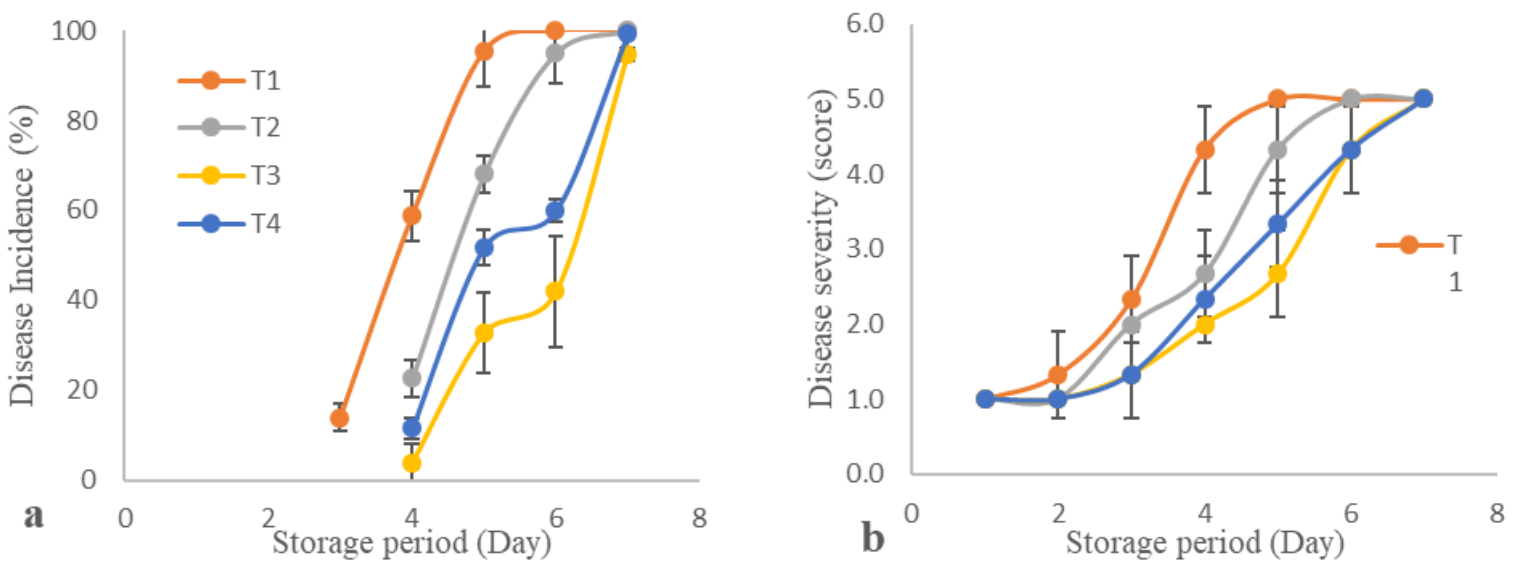

Figure 2. Effect of BPE on changes in (a) disease incidence and (b) disease severity

acetone extract (T2) were infected on day seven. On the other hand, T3 and T4 samples were infected around 94 and $99 \%$ on day seven.

Disease severity analysis indicated the similar observation as the highest retention of acceptable disease severity's score ( $3=$ small brown areas) was found for samples with treatment T4, which was followed by T3, $\mathrm{T} 2$ and $\mathrm{T} 1$. The antimicrobial activity of the banana peel had an impact on lowering disease incidence and disease severity. Tabassum et al. (2018), Hossain and Iqbal (2016) and Bagwan (2001) also reported the same observation in case of disease incidence and severity of banana samples with clear indication of better acceptability for treated samples than control.

\subsection{Effect of BPE on TSS ( ${ }^{\circ}$ Brix) and $p H$}

Total soluble solids (TSS) of the bananas increased with increasing of time as shown in Figure 3(a) and the control sample (T1) had higher TSS increasing rate than the others. Youryon and Supapvanich (2017) reported the TSS value of ripe banana as around $28^{\circ}$ Brix whereas the value increased to around $30^{\circ}$ Brix when bananas were over ripen. Increasing of TSS during storage was also found by Hossain and Iqbal (2016), Siddiqua et al. (2018) and Tabassum et al. (2018). Moreover, these researchers reported that the bananas treated with different extracts showed lower TSS increasing rate than the control as similar as found in this study. However, variation in initial TSS content of the bananas taken for this study and that of other researchers might be due to varietal difference and environmental conditions during harvesting.

The $\mathrm{pH}$ content is also a good quality measure for fruits and vegetables during the storage period. The changes in $\mathrm{pH}$ of the four different treated samples are shown in Figure 3(b) and it is seen that $\mathrm{pH}$ increases gradually with the increase of storage time. The control samples (T1), on the very first day of observation, had $\mathrm{pH}$ of 4.66 which increased to 6.14 on day seven. On the other hand, the BPE treated samples had the $\mathrm{pH}$ values in the range of 4.62 to $6.04,4.66$ to 5.90 and 4.62 to 5.97 for T2, T3 and T4 respectively. Increase of $\mathrm{pH}$ indicates lowering of the stability of the samples. On accordance to Newilah (2009), pH of ripe banana pulp was as 4.365.00 which changed to 4.59-5.54 after complete ripening during storage. In addition, acidity which has a relationship with $\mathrm{pH}$ changed at increasing rate during storage and this rate was higher for control sample than the samples treated with chitosan (Hossain and Iqbal, 2016), neem leaf extract and hot water (Siddiqua et al., 2018), and guava leaf and lemon extracts (Tabassum et al., 2018). This study had a similar observation as mentioned authors above.

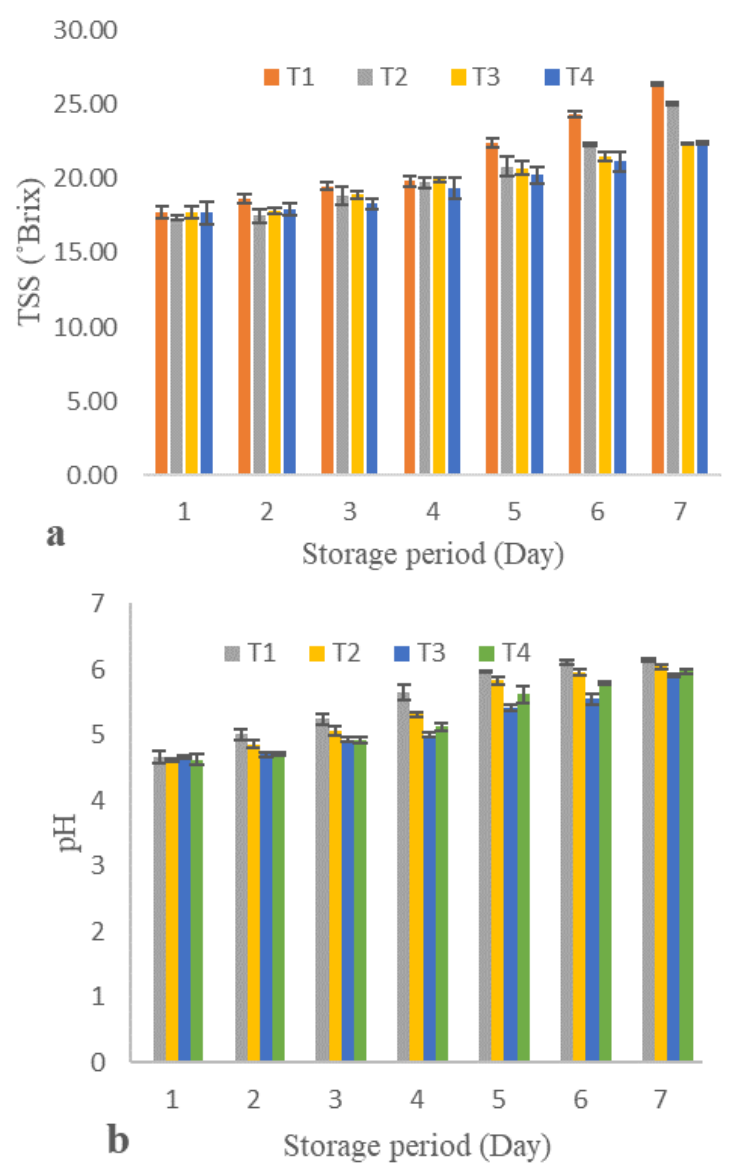

Figure 3. Effect of BPE on changes in (a) TSS and (b) $\mathrm{pH}$ 


\subsection{Effect of BPE on Weight Loss}

There were more differences in the weight loss of untreated bananas (T1) than other treated bananas (T2, T3 and T4) as shown in Figure 4. The control sample lost weight at a faster rate than others. After seven days of storage, it was observed that the weight loss of $\mathrm{T} 1, \mathrm{~T} 2$, $\mathrm{T} 3$ and $\mathrm{T} 4$ was as 10.03, 6.50, 5.73 and $6.20 \%$ respectively which indicated that the BPE extract of ethanol had more weight retention capacity, followed by the BPE of distilled water and acetone. These findings revealed that the BPE has an impact to retain water as well as good structure of banana. A similar observation was reported by Hossain and Iqbal (2016), Siddiqua et al. (2018) and Tabassum et al. (2018) who found that bananas storage without treatment lost weight faster than other bananas with different postharvest treatments.

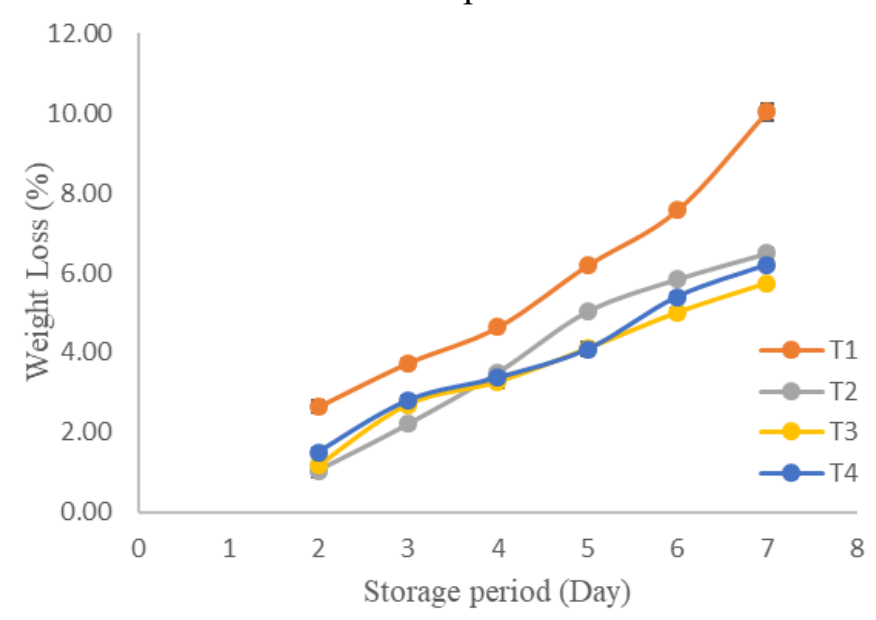

Figure 4. Effect of BPE on weight loss

\subsection{Effect of BPE on shelf life of banana}

Table 1. Influence of BPE on the shelf life of banana

\begin{tabular}{ccc}
\hline Treatments & Shelf life (days) & LSD $(P \leq 0.05)$ \\
\hline T1 & $3.05 \pm 0.39^{\mathrm{d}}$ & \\
T2 & $4.15 \pm 0.37^{\mathrm{c}}$ & 0.26 \\
T3 & $6.10 \pm 0.45^{\mathrm{a}}$ & \\
T4 & $5.20 \pm 0.41^{\mathrm{b}}$ & \\
\hline
\end{tabular}

Different superscripts within the same column indicate difference at $5 \%$ level of significance.

According to the different acceptable limits described above, the acceptable shelf life (in days) of different treatment is shown in Table 1. Where the control (T1) had the least shelf life of $3.05 \pm 0.39$ days and the other treatments showed the shelf life of $4.15 \pm 0.37$ days, $6.10 \pm 0.45$ days and $5.20 \pm 0.41$ days for $\mathrm{T} 2, \mathrm{~T} 3$ and T4 respectively. Statistical analysis indicated that storage life differed significantly from each other treatments. The best shelf life was observed for BPE of ethanol, where preservation capacity of ethanol may also have an effect combining with banana peel to increase shelf life. Longer shelf life of fruits and vegetables was also reported by Stephen (2014) while observing the combined effect of guava leaf extract $(20 \%)$ and lemon extract (15\%). However, from this study, it was found that BPE has preservation capability to extend the shelf life of bananas.

\section{Conclusion}

Banana peel extracts obtained using different solution showed a significant impact on the post-harvest storage stability of ripe banana. Desirable changes in different parameters as physical (weight loss, color, firmness and flavor), chemical (TSS, $\mathrm{pH}$ ) and microbial (disease severity and disease incidence) was observed for the samples treated with BPE. The best results were found for the treatment of banana peel with $80 \%$ ethanol (T3) followed by the distilled water treatment (T4) and acetone treatment (T2). So considering the findings of the current study, it could be concluded that banana peel extract maintained a positive impact on the desired physicochemical characteristics during the storage of banana (Sagar cultivar) at ambient conditions. However, further study can proceed on process optimization of BPE preparation and application as well as on the microbial, proximate, minerals and antioxidant analysis during storage.

\section{References}

Akter, H., Hassan, M.K., Rabbani, M.G. and Mahmud, A.A. (2013). Effects of variety and postharvest treatments on shelf life and quality of banana. Journal of Environmental Sciences and Natural Resources, 6(2), 163- 175. https://doi.org/10.3329/ jesnr.v6i2.22113

Aurore, G., Parfait, B. and Fahrasmane, L. (2009). Bananas, raw materials for making processed food products. Trends in Food Science and Technology, 20(2), 78-91. https://doi.org/10.1016/ j.tifs.2008.10.003

Bagwan, N.B. (2001). Anthracnose of banana fruits and its management with plant extracts, Aerobiology, Mycology and Pathology laboratory. Current Research University of Agricultural Science Bangalore, 30(11/12), 197-198.

Basel, R.M., Racicot K. and Senecal, A.G. (2002). Long shelf life banana storage using MAP storage coupled with postharvest MCP treatment presented at the Annual Meeting, Institute of Food Technologists, 1 June 2002. Anaheim, California, USA: Institute of Food Technologist.

BBS (Bangladesh Bureau of Statistics). (2016). Yearbook of Agricultural Statistics of Bangladesh. Bangladesh: Ministry of planning, Government of the People's Republic of Bangladesh.

Begam, M.S., Das, P.C., Hossain, M.N. and Iqbal, A. 
(2018). Assessment of Bioactive Activity of Blackberry Seed Extract. International Journal of Trend in Scientific Research and Development (IJTSRD), 2(5), 1597-1605. https://doi.org/10.31142/ ijtsrd 15947

Chabuck, Z.A.G., Al-Charrakh, A.H., Hindi, N.K.K. and Hindi, S.K.K. (2013). Antimicrobial effect of aqueous banana peel extract, Iraq. Research Gate: Pharmaceutical Sciences, 1, 73-75.

Dadzie, B.K. and Orchard, J.E. (1997). Routine post harvest screening of banana/plantain hybrids: criteria and methods. INIBAP Technical Guidelines 2., p. 26. Rome, Italy: International Plant Genetic Institute.

Dang, K.T.H., Singh, Z. and Swinny, E.E. (2008). Edible coatings influence fruit ripening, quality, and aroma biosynthesis in mango fruit. Journal of Agricultural and Food Chemistry, 56, 1361-1370. https:// doi.org/10.1021/jf072208a

Habiba, U. (2012). Effects of different plant extracts on shelf life and quality of banana. Mymensingh, Bangladesh: Bangladesh Agricultural University, MSc. Thesis.

Hassan, M.K. (2010). A guide to postharvest handling of fruits and vegetables., p. 19-22. Mymensingh, Bangladesh: Ali Press

Hossain, M.S. and Iqbal, A. (2016). Effect of shrimp chitosan coating on postharvest quality of banana

(Musa sapientum L.) fruits. International Food Research Journal, 23(1), 277-283.

Islam, M.S. (2012). Effects of plant extracts on the extension of shelf life of papaya without affecting the postharvest quality of fruits. Mymensingh, Bangladesh: Bangladesh Agricultural University, MSc. Thesis.

Kapadia, S.P., Pudakalkatti, P.S. and Shivanaikar, S. (2015). Detection of antimicrobial activity of banana peel (Musa paradisiaca L.) on Porphyromonas gingivalis and Aggregatibacter actinomycetemcomitans: An in vitro study. Contemporary Clinical Dentistry, 6(4), 496-499. https://doi.org/10.4103/0976-237X.169864

Kaur, P. (2016). Shelf life enhancement studies in guava (Psidium guajava L.) cv. shweta. Ludhiana: Punjab Agricultural University, MSc. Thesis.

Kittur, F.S., Saroja, N. and Tharanathan, H.R.N. (2001). Polysaccharide-based composite coating formulations for shelf life extension of fresh banana and mango. European Food Research and Technology, 213(4-5), 306-311. https:// doi.org/10.1007/s002170100363

Le, P.T.Q. and Truong, H.D. (2015). Effect of Nopal Gel Solution on the Preservation of Banana (Musa
Paradisiaca). Agricultural and Biological Sciences Journal, 1(3), 95-99.

Malik, A.A., Bhat, A., Ahmed, N. and Kaul, R. (2015). Effect of postharvest application of plant extracts on physical parameters and shelf life of guava. Asian Agri-History, 19(3), 185-193.

Molla, M.M., Islam M.N., Nasrin T.A.A., Salam, M.A. and Hoque, M.A. (2012). Survey on postharvest practices and losses of banana in selected areas of Bangladesh. Bangladesh Journal of Agriculture Research, 37(1), 27-35.

Newilah, G.N., Tomekpe, K., Fokou, E. and Etoa, F.X. (2009). Physicochemical Changes during Ripening of Bananas Grown in Cameroon. Fresh Produce, 3 (1), 64-70. https://doi.org/10.1051/fruits/2009015

Sarmin, R.A., Khan, S.A.K.U., Fatema, K. and Sultana, S. (2018). Effect of neem leaf and banana pulp extracts on shelf life and quality of mango (Mangifera indica L.). Journal of Bangladesh Agricultural University, 16(3), 343-350. https:// doi.org/10.3329/jbau.v16i3.39488

Shadma, A., Sundaram, S. and Rai, G.K. (2014). Nutraceutical application and value addition of banana peel: A review. International Journal of Pharmacy and Pharmaceutical Sciences, 6, 81-85.

Siddiqua, M., Khan, S.A.K.U., Tabassum, P. and Sultana, S. (2018). Effects of neem leaf extract and hot water treatments on shelf life and quality of banana. Journal of Bangladesh Agricultural University, 16(3), 351-356. https://doi.org/10.3329/ jbau.v16i3.39389

StatGraphics. (1999). Advanced Regressions. Using Logistic Regression. In User Manual (Chapter 7). StatGraphics Plus for Windows. Version 5.1. Professional edition. Rockville, MD. USA: Manugistic, Inc.

Stephen, T.T. (2014). Feasibility study of the guava leaves extract as a natural preservatives for vegetables and fruits. Tigbauan, lloilo, Philippines: Napnapan national high school

Stewart, O.J., Raghavan, G.S.V., Golden, K.D. and Gariepy, Y. (2005). MA storage of cavandish banana using silicone membrane and diffusion channel systems. Postharvest Biology and Technology, 35(3), 309-317.

https://doi.org/10.1016/

j.postharvbio.2004.10.003

Tabassum, P., Khan, S.A.K.U., Siddiqua, M. and Sultana, S. (2018). Effect of guava leaf and lemon extracts on postharvest quality and shelf life of banana cv. Sabri (Musa sapientum L.). Journal of Bangladesh Agricultural University, 16(3), 337-342. https://doi.org/10.3329/jbau.v16i3.39489 
Tchobanoglous, G., Theisen, H. and Vigil, S. (1993). Integrated Solid Waste Management: Engineering Principals and Management Issues. Boston, MA, USA: McGraw-Hill, Inc.

Ullah M.H. (2007). Effect of postharvest treatments on the prolongation of shelf life of banana. Mymensingh, Bangladesh: Bangladesh Agricultural University, MSc. Thesis.

Youryon, P. and Supapvanich, S. (2017). Physicochemical quality and antioxidant changes in 'Leb Mue Nang' banana fruit during ripening. Agriculture and Natural Resources, 51(1), 47-52. https://doi.org/10.1016/j.anres.2015.12.004 